\title{
Effect of X-rays on structural, physicochemical and functional properties of gluten protein
}

\author{
Efeito dos raios $X$ nas propriedades estruturais, físico-químicas \\ e funcionais da proteína de glúten
}

\author{
Durga Chandra ${ }^{1}$, Ashish Dabade ${ }^{1 *} \mathbb{0}$, Gauri Damgude ${ }^{1}$, Chetali Malhotra1 \\ ${ }^{1}$ D.Y. Patil Deemed to be University, School of Biotechnology and Bioinformatics, Navi Mumbai - India
}

*Corresponding Author: Ashish Dabade, D.Y. Patil Deemed to be University, School of Biotechnology and Bioinformatics, Food Science and Technology, CBD Belapur, Navi Mumbai - India, e-mail:

ashish.dabade@dypatil.edu

Cite as: Chandra, D., Dabade, A., Damgude, G., \& Malhotra, C. (2021). Effect of X-rays on structural, physicochemical and functional properties of gluten protein. Brazilian Journal of Food Technology, 24, e2020074. https://doi.org/10.1590/1981-6723.07420

\begin{abstract}
The gluten protein was exposed to the $\mathrm{X}$-ray radiations for different time range, comprising 1 and 3 seconds. The objective of this study was to determine the effect of $\mathrm{x}$-ray radiations on the physicochemical properties of gluten protein. Different functional properties of proteins like water and oil holding capacities, protein solubility, emulsification activity, and stability index, foaming action and stability, water solubility, protein, and moisture content, along with SDS PAGE, FTIR, Xeta potential net charge was carried out to evaluate the effect of X-ray radiation on gluten protein. Results showed that the enhancement of water holding capacity up to $38.12 \%$, as well as oil holding capacity up to $35 \%$ could be seen, whereas a significant decrease in emulsification activity and stability index, foaming capacity and stability, even protein content could be observed in treated samples. The net charge on protein in water solution was found to increase towards the positive side. The structure of the protein remained unchanged based on no change was observed in SDS PAGE electrograph, FTIR secondary structure region. Hence, $\mathrm{X}$-ray treatment can be a possible way to alter the protein structure for "tailor-made applications" in food industries.
\end{abstract}

Keywords: Gluten; X-ray; Protein structure; Water and oil holding; Foaming capacity and stability; Emulsion capacity and stability; Net charge.

\section{Resumo}

A proteína do glúten foi exposta à radiação de raios $X$ por diferentes intervalos de tempo, entre 1 e 3 segundos. $O$ objetivo deste estudo foi determinar o efeito das radiações de raios $\mathrm{X}$ nas propriedades físico-químicas da proteína do glúten. Diferentes propriedades funcionais de proteínas como capacidade de retenção de água, capacidade de retenção de óleo, solubilidade de proteínas, atividade de emulsificação e índice de estabilidade, ação e estabilidade da espuma, solubilidade em água, teor de proteína e de umidade, juntamente com SDS PAGE, FTIR, carga líquida do potencial Xeta foram analisadas para avaliar o efeito da radiação de raios $\mathrm{X}$ na proteína de glúten. Os resultados mostraram um aumento da capacidade de retenção de água em até $38,12 \%$, da capacidade de retenção de óleo 
em até 35\%, enquanto verificou-se uma diminuição significativa na atividade de emulsificação e no índice de estabilidade, na capacidade de formação e estabilidade de espuma e no teor de proteína das amostras tratadas. Verificou-se que a carga líquida sobre a proteína na solução aquosa aumentou para o lado positivo. A estrutura da proteína ficou inalterada com base em nenhuma alteração foi observada no eletrógrafo SDS PAGE, região da estrutura secundária do FTIR. Portanto, o tratamento com raios $\mathrm{X}$ pode ser utilizado para alterar a estrutura da proteína visando aplicações específicas na indústria de alimentos.

Palavras-chave: Glúten; Raios X; Estrutura de proteínas; Retenção de água e óleo; Capacidade de formação e estabilidade de espuma; Capacidade e estabilidade de emulsões; Carga líquida.

\section{Introduction}

Food irradiation includes the exposure of macronutrient to gamma rays or high energy electrons or X-rays. It has been proved that irradiation changes food properties and functions. According to codex general standard for irradiated food, the X-rays can be used up to $7.5 \mathrm{MeV}$. X-rays are considered as the optimum choice for radiation treatment because they do not cause induced radioactivity in food products; in addition, the cost of production of X-ray is less expensive when compared to gamma radiation. The penetrating power of X-ray creates an excellent way to modify the macromolecules of food (Farkas, 2006).

The ionization energy of $\mathrm{X}$-rays reduces when it passes through the food. This absorbed energy produced by the radiation creates an effect on macromolecules like protein, which can achieve the ionic state in food. The radicals like $\mathrm{OH}, \mathrm{e}^{-}$aq, $\mathrm{H}$, with $\mathrm{H}_{2} \mathrm{O}_{2}, \mathrm{H}_{3} \mathrm{O}^{+}$may be formed during the exposure reactions. These radicals react with amino acids of protein and cause decarboxylation reaction, which produces amine and aldehydes. Sulfur-containing and aromatic amino acids are most susceptible to irradiation (Molins, 2001). The changes in optical properties are also observed due to oxidation of amino acids, as well as to the formation of dimers with irreversible changes in proteins (Barron \& Finkelstein, 1952). The accumulation of a large number of energy results in the denaturation of protein consisting of changes in the secondary and tertiary structures of proteins, however, without changing the nutritional values of them. Currently, ionizing radiation (X-ray) is only using for Radio pasteurization, Radurization, Radappertization (Harder et al., 2015). About $80 \%$ of the protein of wheat flour is composed of gluten. Gluten proteins are formed from gliadins and glutenins. They are profoundly characterized as polymorphic polypeptides of molecular weight about 30,000 to 90,000 kDa. These protein subunits are functional subunits for viscosity, elasticity (Kovacs et al., 2004).

The functional properties of protein-dependent pathways depend on the structure of the protein. The alternation in protein structure may lead to change in the functionality of protein like protein solubility, emulsification properties, foaming properties (Yalcin et al., 2008). Most of the ionization study was focused on gamma radiation based on effects of protein. The need for X-ray analysis based on protein is another area that there is lack of studies regarding the details of vegetable and protein functions. The study has conducted to determine the effect of X-ray radiations on functional properties of proteins like water and oil holding capacities, protein solubility, emulsification activity, and stability, Foaming Capacity (FC) and Foaming Stability (FS).

\section{Materials and method}

\subsection{Materials}

Gluten protein powder was purchased from Agridient manufacturers (purity 85\%) in Mumbai. Sodium tartrate, copper sulfate, 10\% sodium hydroxide, SDS, Acrylamide, Bis-acrylamide, Glycine, Commasiae Brilliant Blue R-250, Methanol, GAA, Glycerol, Bromophenol blue, $\beta$-mercaptoethanol, TEMED chemicals were purchased from Himedia, sigma, and SRL laboratory. 


\subsection{Methods}

\subsubsection{Treatment}

Around 200 grams of Gluten protein powder were exposed to X-rays at $108 \mathrm{kV}$ for $1 \mathrm{sec}$ and 3 seconds by X-ray machine (Make- RMS) and then they were labeled as GLU 1 and GLU 3 respectively. The functional properties of these gluten protein powder were studied and compared against untreated gluten protein powder. The samples were frozen immediate at $-40{ }^{\circ} \mathrm{C}$.

\subsubsection{Assays of proximate analysis of $x$-ray treated sample}

The protein was analyzed for protein content changes after X-ray treatment. Protein determination was carried out by Kjheldhal Method (Roger et al., 2007).

\subsubsection{Water holding capacity}

Water holding capacity was determined by the method outlined by Yu et al. (2007). 0.5 grams of gluten protein flour was weighed into pre-weighed $15-\mathrm{mL}$ centrifuge tubes. For each sample, an amount of $5 \mathrm{~mL}$ of distilled water was added and mixed using a vortex at the highest speed for $2 \mathrm{~min}$. Samples were allowed to stand at room temperature for $30 \mathrm{~min}$ after the mixture was thoroughly wetted. Then centrifuged at $2000 \mathrm{rpm}$ for $30 \mathrm{~min}$. The supernatant was decanted, and the centrifuge tube containing sediment was weighed. Water holding capacity (grams of water per gram of protein) was calculated with Equation 1.

$$
W H C=\frac{W 2-W 1}{W 0}
$$

Where W0 is the weight of the dry sample (g), W1 is the weight of the tube plus the dry sample (g), and $\mathrm{W} 2$ is the weight of the tube plus the sediment $(\mathrm{g})$. Triplicate samples were analyzed for each sample.

\subsubsection{Oil holding capacity}

Oil holding was determined by the method outlined by Yilmaz \& Emir (2016). 0.5 gram of protein sample was weighed into the tube, and an amount of $5 \mathrm{~mL}$ of sunflower oil was added into it. The sample was dispersed in oil by vortexing for $30 \mathrm{~min}$; the mixture was allowed to stand for $30 \mathrm{~min}$ at room temperature and then centrifuged at $5888 \mathrm{rpm}$ for $15 \mathrm{~min}$. An additional $5 \mathrm{~min}$ centrifugation at $17000 \mathrm{rpm}$ was done before inverting the tubes to drain the free oil out for 1 hour. Finally, the absorbed oil was calculated from the weight difference, and Oil Holding Capacity $(\mathrm{OHC})$ was reported as g oil/g protein.

\subsubsection{Emulsion activity and stability index}

Emulsifying activity and emulsion stability were determined with slight modifications. An emulsion of various concentration $0.25 \%, 0.5 \%, 0.75 \%$, and $1 \%$ was prepared by mixing $0.5 \mathrm{~g}$ of gluten protein sample in $5 \mathrm{~mL}$ distilled water and then vortexed for $1 \mathrm{~min}$, then an amount of $5 \mathrm{~mL}$ sunflower oil was added and homogenized at $8,000 \mathrm{rpm}$ for $3 \mathrm{~min}$ at $25^{\circ} \mathrm{C}$ (Ballesteros et al., 2014; Chau et al., 1997). Then $50 \mu \mathrm{L}$ of the emulsion was diluted with $5 \mathrm{~mL}$ of $0.1 \%$ (w/v) sodium dodecyl sulfate (SDS) solution. The absorbance of the emulsion was measured immediately after emulsion formation using UV-Visible spectroscopy at $500 \mathrm{~nm}$ and expressed as emulsion activity of the protein was calculated using Equation 1 (Li et al., 2014; Sui et al., 2017). To determine the emulsion stability index, the emulsion was left at $25^{\circ} \mathrm{C}$ for $10 \mathrm{~min}$, and then $50 \mu \mathrm{L}$ of the emulsion was diluted with $5 \mathrm{~mL}$ of $0.1 \%(\mathrm{w} / \mathrm{v})$ SDS solution and the absorbance at $500 \mathrm{~nm}$ was measured (Jongjareonrak et al., 2015). Emulsion activity and stability index were calculated according to the following Equations 2 and 3: 


$$
\begin{gathered}
E A I\left(m^{2} / g\right)=\frac{2 \times T \times A O \times N}{10000 \times \theta \times L \times C} \\
E S I(\min )=\frac{A O \times(T 10-T O)}{A O-A 10}
\end{gathered}
$$

Where T equals to 2.303; $\mathrm{A} 0$ is the absorbance at $0 \mathrm{~min} ; \mathrm{N}$ is the dilution factor; $\theta$ is the proportion of the oil phase (0.25); $\mathrm{L}$ is the thickness of the cuvette $(1 \mathrm{~cm}) ; \mathrm{C}$ is the concentration of gluten protein $(\mathrm{g} / \mathrm{mL}) ; \mathrm{A} 10$ is the absorbance at $10 \mathrm{~min}$; T0 represents $0 \mathrm{~min}$; and T10 represents $10 \mathrm{~min}$ (Sui et al., 2017).

\subsubsection{Foaming capacity and foaming stability}

The foaming capacity -FC and foaming stability - FS were determined according to the method of CanoMedina et al. (2011) and Yilmaz \& Emir (2016) with slight modification. The FC and FS were examined for a supernatant sample of various concentrations $(0.5 \%, 1 \%, 1.5 \%$, and $2 \%)$ by dissolving them in distilled water and they were whipped at high speed with a hand blender and poured into $100 \mathrm{~mL}$ volumetric cylinder.

The FC was reported by the Formula 4 below,

$$
F C(\%)=\frac{(\text { volume after aitation }- \text { volume prior to agitation })}{\text { volume prior to agitation }} \times 100
$$

The samples were allowed to stand for $30 \mathrm{~min}$ at room temperature to estimate the FS given by the Formula 5 below,

$$
F S(\%)=\frac{\text { residual foam volume }}{\text { total foam volume }} \times 100
$$

\subsubsection{Solubility}

Solubility was determined by the method outlined by Chang \& Zhang (2017). A 5-mL biuret reagent was mixed with a $1-\mathrm{mL}$ portion of protein solution ( 1 to $10 \mathrm{mg}$ protein $/ \mathrm{mL}$ ). The reagent includes copper sulfate, $\mathrm{NaOH}$, and potassium sodium tartrate, which was used to stabilize the cupric ion in the alkaline solution. After the reaction, mixture was allowed to stand at room temperature for 15 or $30 \mathrm{~min}$, the absorbance was read at $540 \mathrm{~nm}$ against a reagent blank. A standard curve of concentration versus absorbance was developed using Bovine Serum Albumin (BSA).

\subsubsection{SDS PAGE}

Determination of molecular weight changes was performed by (Babiker et al., 1996) method with slight modification. method with slight modification. SDS-poly-acrylamide gel electrophoresis (SDS-PAGE) of freeze-dried samples was done using 12\% acrylamide separating gel and 5\% acrylamide stacking gel containing $0.1 \%$ SDS. $7 \mathrm{~mL}$ of $12 \%$ resolving gel was poured in the gel unit and allowed to polymerize. After $45 \mathrm{~min}, 3 \mathrm{~mL}$ of $5 \%$ stacking gel was poured, and the comb was inserted, and then tris glycine buffer was loaded into the upper and lower chambers and kept for $1 \mathrm{~h}$. After that, $35 \mu \mathrm{L}$ of the sample was prepared in a Tris-glycine buffer at pH 6.8 containing 2\% SDS was loaded into wells of gel unit. Electrophoresis was done at a current of $60 \mathrm{~mA}$ for $1 \mathrm{~h}$, and after that at $80 \mathrm{~mA}$ for $2 \mathrm{~h}$. After electrophoresis, the gel sheets were stained with $0.2 \%$ Coomassie brilliant blue-R250 and destained with 10\% acetic acid containing 30\% methanol for $18 \mathrm{~h}$ to remove any traces of the staining solution. 


\section{Result and discussion}

\subsection{Water holding capacity}

The water absorption capacity of GLU 00, GLU 1, and GLU 3 was $1.60 \mathrm{gm} / \mathrm{gm}, 1.78 \mathrm{gm} / \mathrm{gm}$, and $2.21 \mathrm{gm} / \mathrm{gm}$, respectively. Approximately $11.25 \%$ and $38.12 \%$ of water holding capacity could be increased (Figure 1). This indicates that the water holding capacity could increase by increasing the exposure time of X-ray. All three samples were found to be significantly different $(p<0.05)$ from each other. This gradual increase may be owing to an irradiation that leads to protein denaturation (Pollard, 1960). Protein denaturation leads to unfolding and exposure of hydrophilic groups Or due to an increase in charge of amino acid profiling (Margesin \& Schinner, 1999). Consistent with our study, WHC of KPS20 and KPM20 was influenced by irradiation treatment (Lee et al., 2017). The water holding capacity of dough is considered an essential factor in the food processing of various bakery products (Kaushik et al., 2015).

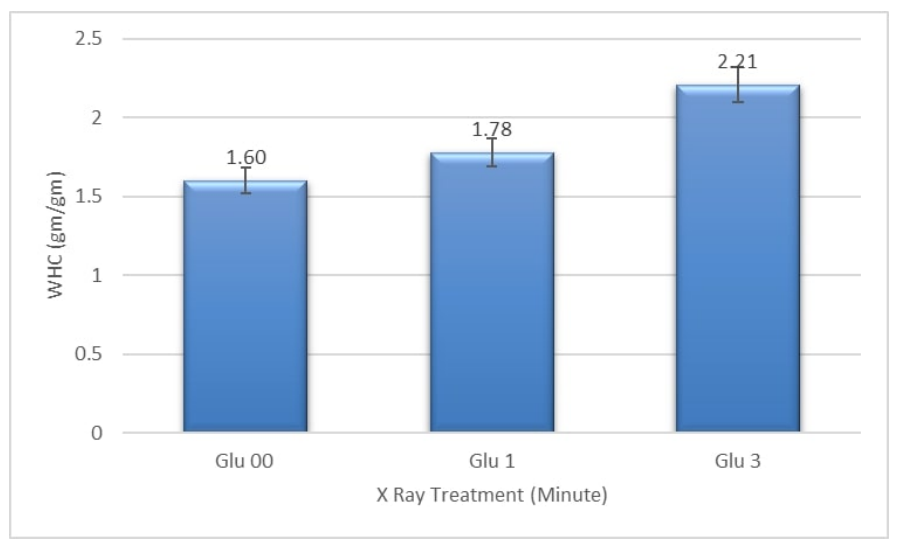

Figure 1. Gaph of Water Holding Capacity of GLU 00, GLU 1, and GLU 3 ( $n=3)$.

\subsection{Oil holding capacity}

The obtained values of GLU 00, GLU 1, and GLU 3 were 0.96/gm, 1.29/gm, and 1.74/gm, respectively (Figure 2). A significant increase in oil holding capacity was observed as the exposure time of radiation was increased. $34.37 \%$ and $81 \%$ of oil absorption enhancement could be found in the $\mathrm{x}$-ray treatment consisting of 1 and 3-minute samples. This increase should be observed due to the exposure of more hydrophobic regions associated with crosslinking reactions (Hmed \& Osman, 2009). The oil absorption capacity is a vital parameter during frying and cooking of noodles and pasta (Kaushik et al., 2015).

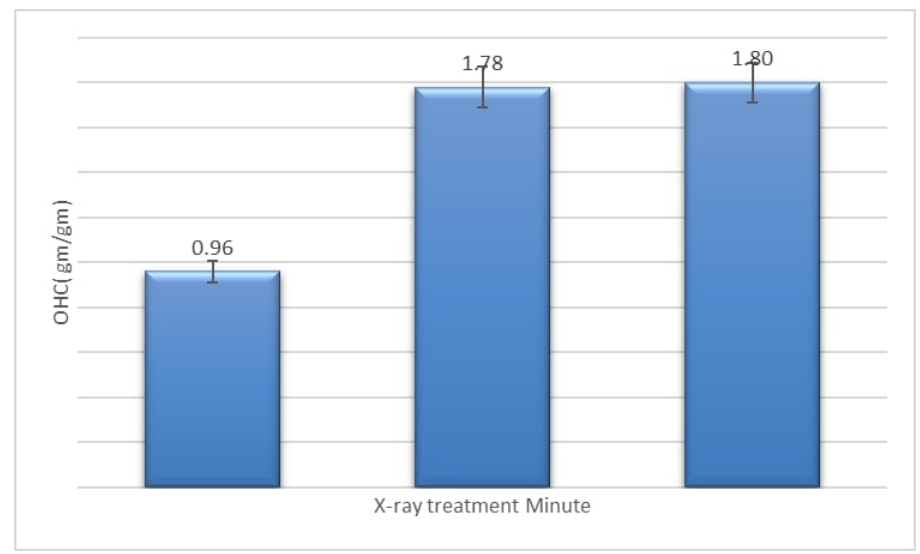

Figure 2. Oil Holding Capacity of GLU 00, GLU 1, and GLU 3 ( $n=3)$. 


\subsection{Emulsion activity index and emulsification stability index}

The Emulsion Activity Index (EAI) values of GLU 00, GLU 1, and GLU 3 were $0.54 \mathrm{~m}^{2} / \mathrm{g}, 0.27 \mathrm{~m}^{2} / \mathrm{g}$, and $0.25 \mathrm{~m}^{2} / \mathrm{g}$, respectively. The Emulsification Stability Index (ESI) values of GLU 00, GLU 01, and GLU 3 were $70 \mathrm{~min}, 52 \mathrm{~min}$, and $63 \mathrm{~min}$, respectively (Figure 3). Significantly decrease in EAI and ESI might have occurred since irradiation leads to denaturation and aggregation of the protein molecule, particularly at high dosage. Therefore it can be noted that emulsifying properties changed significantly after irradiation. Consistent with our study, the EAI and ESI decreased the interfacial tension of sorghum grains after irradiation (Ahmed et al., 2018).

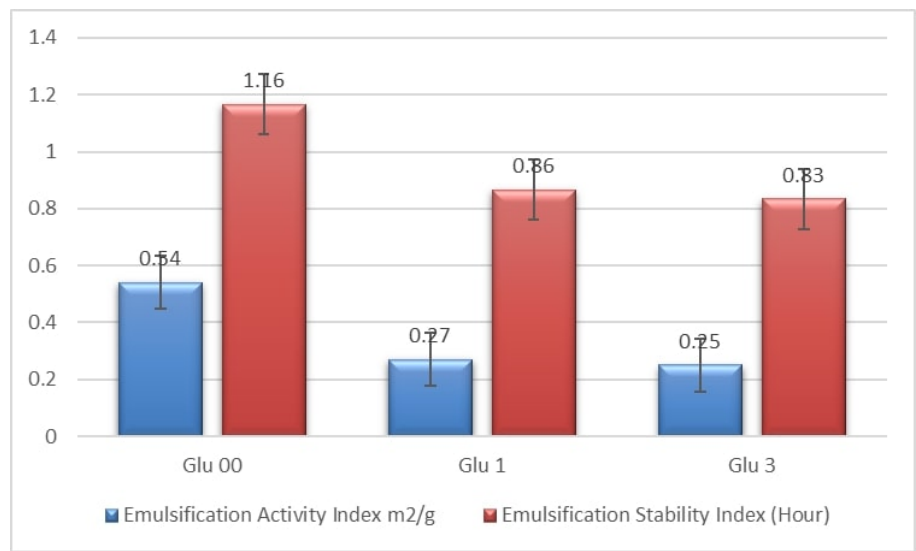

Figure 3. Emulsifying Activity Index of GLU 00, GLU 1, and GLU 3 ( $n=3)$.

\subsection{Foaming capacity of gluten protein}

The effects of X-ray irradiation on the foaming properties are shown in Figure 4. The FC of GLU 00, GLU 1 , and GLU 3 showed a significant decrease in FC $(p<0.05)$. This change in decrease might be associated with the ionizing radiation that would have change the solubility and protein nature. Ionizing irradiation promotes change in proteins and may lead to a change in foaming properties (Ahmed et al., 2018). Furthermore, the FS was unchanged. The FS of GLU 00, GLU 1, and GLU 3 was $77 \%, 74 \%, 70 \%$, respectively. The FS of all the three samples, such as GLU 00, GLU 1, and GLU 3, were significantly different from each other.

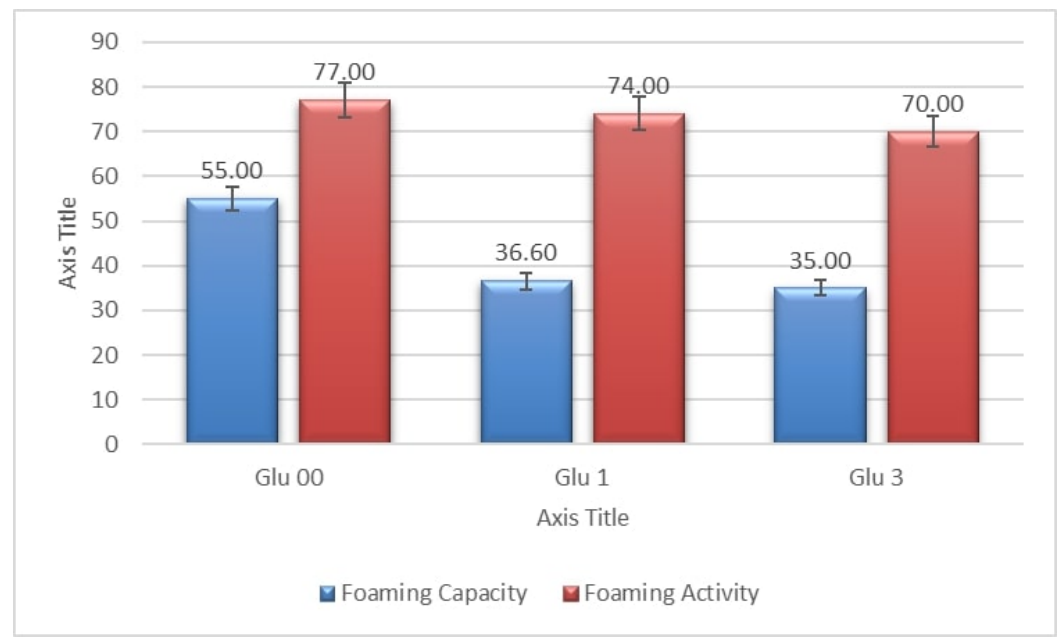

Figure 4. Foaming activity and stability of GLU 00, GLU 1, and GLU 3 ( $n=3)$. 


\subsection{Protein content}

Figure 5 shows the protein content present in gluten protein. It was estimated by the Kjeldahl method, in which the crude protein content of the food could be evaluated since nitrogen is also referred to non-protein components(Chang \& Zhang, 2017).

The protein contents in GLU 00, GLU 1, and GLU 3 were 870.05\%, 85.83\%, and 85.22\%, respectively. A significant decrease $(p<0.05)$ in protein percentage was observed in X-ray treated samples. Irradiation leads to denaturation in which proteins can be unfolded, and structure might have destabilized (Pollard, 1960).

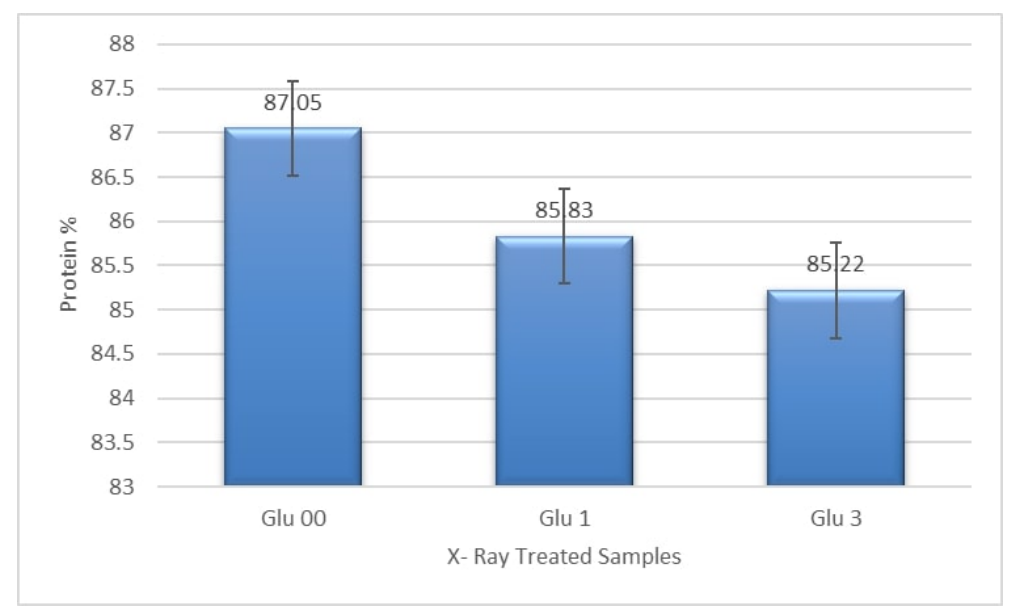

Figure 5. The protein contents of GLU 00, GLU 1 and GLU $3(n=3)$.

\subsection{Moisture content}

Figure 6 shows the moisture content of gluten protein. The moisture contents of GLU 00, GLU 1, GLU 3 were $0.3,0.7,0.9 \%$, respectively. All three samples were significantly different $(p<0.05)$ from each other. The same moisture effect was mentioned by Molins (2001).

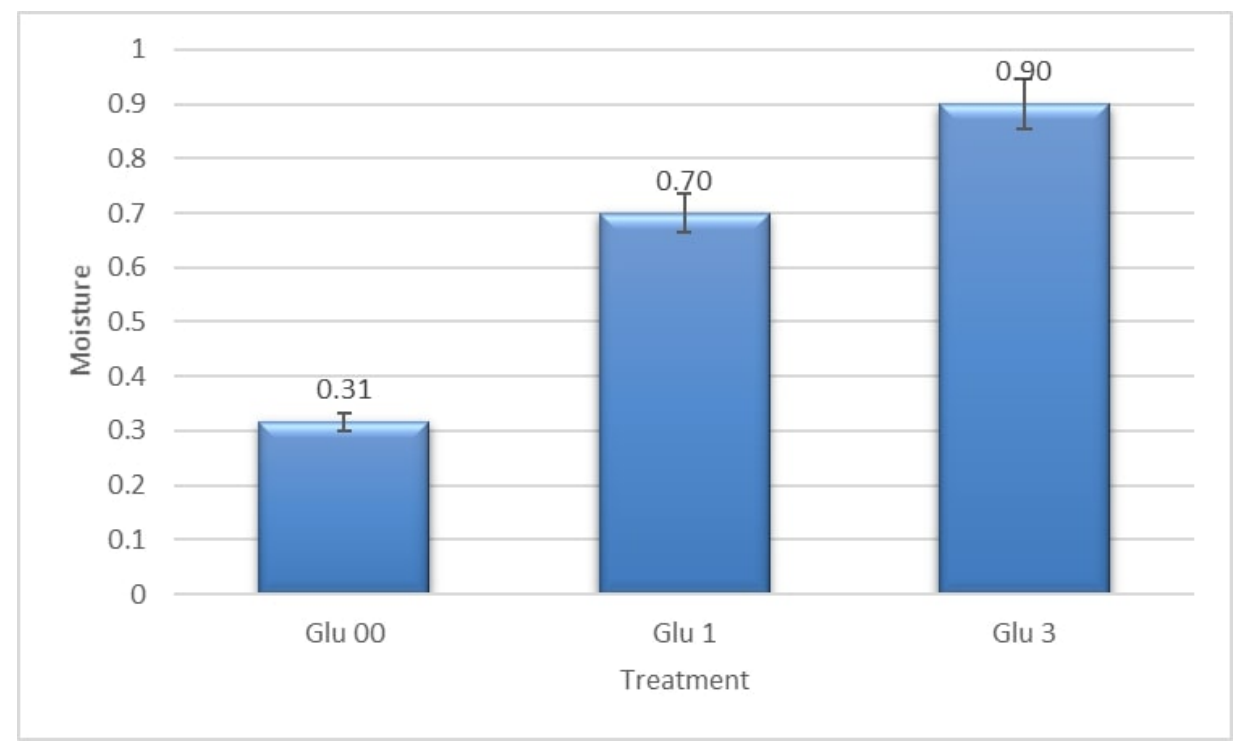

Figure 6. The moisture contents of GLU 00, GLU 1 and GLU 3 (n=3). 


\subsection{Solubility}

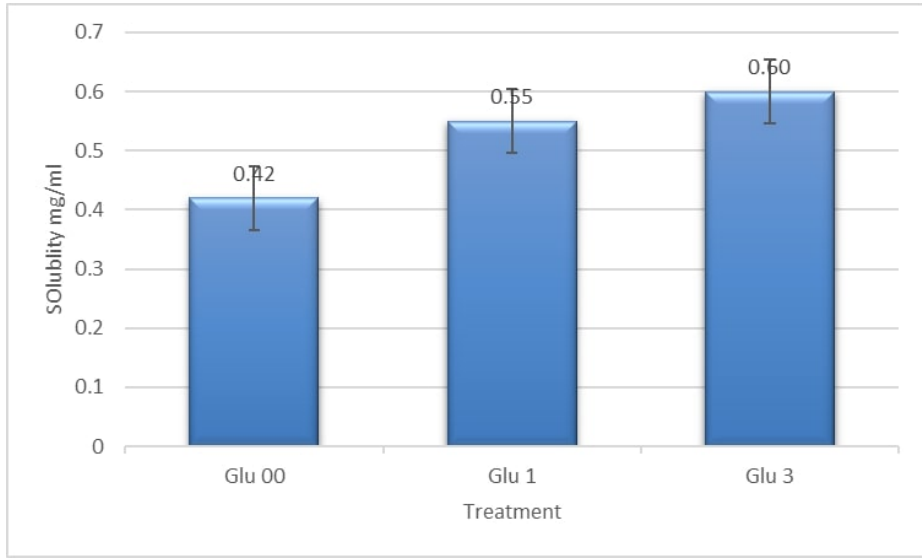

Figure 7. Solubilities of GLU 00, GLU 1 and GLU 3 ( $n=3)$.

The water solubilities of GLU 00, GLU 1, and GLU 3 were $0.4267,0.3767$, and $0.4333 \mathrm{mg} / \mathrm{mL}$, respectively (Figure 7). The increase in water solubility was observed between control and treated samples $(p<0.05)$. This increase might be related to irradiation since it breaks down covalent linkages and might be associated with depolymerization and exposure of hydrophobic groups as explained in Molins (2001).

\subsection{Molecular weight}

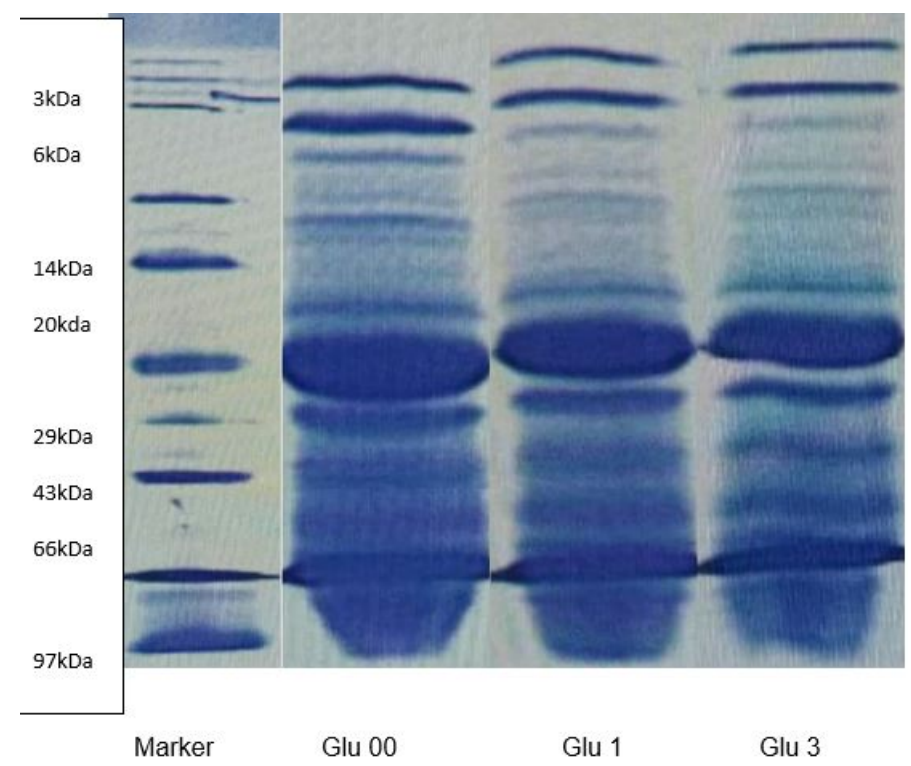

Figure 8. SDS page of GLU 00, GLU 1, and GLU 3.

The glutenin and gliadin fractions in GPP were determined through the SDS page. It was evident from the electropherograms that more significant numbers of polypeptides were present in the region falling within the high molecular weight glutenin subunits. The High-Molecular-Weight Glutenin Subunits (HMW-GS) were ranging between $90 \mathrm{kDa}$ to $200 \mathrm{kDa}$, and Low-Molecular-Weight (LMW) gliadin was ranging between $20 \mathrm{kDa}$ to $50 \mathrm{kDa}$. The X-ray treatment did not show any noticeable effects on the gluten protein in electrophotography (Figure 8). A similar effect was observed in whey protein, where molecular weight should remain unchanged, however, a significant changehas been shown in other protein properties (Segat et al., 2014). 


\subsection{The net charge on emulsion}

A

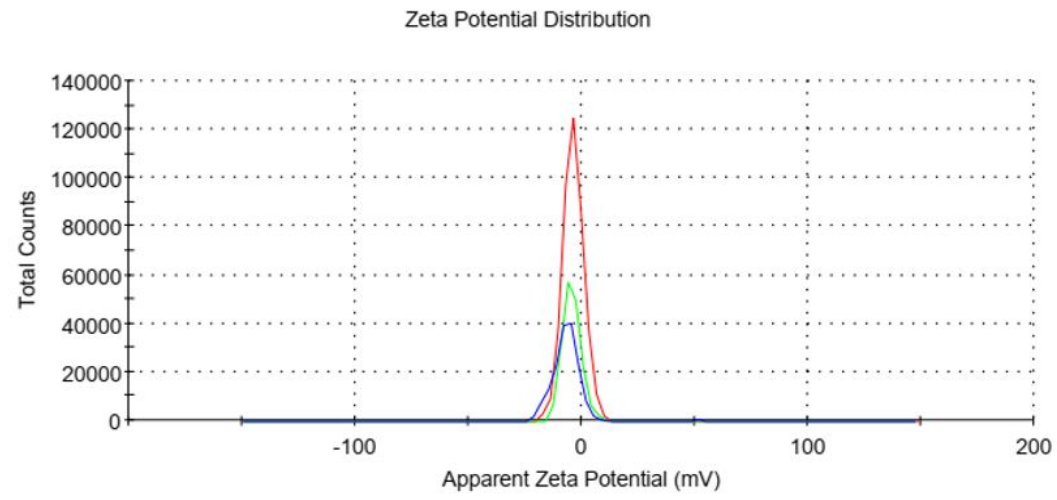

B

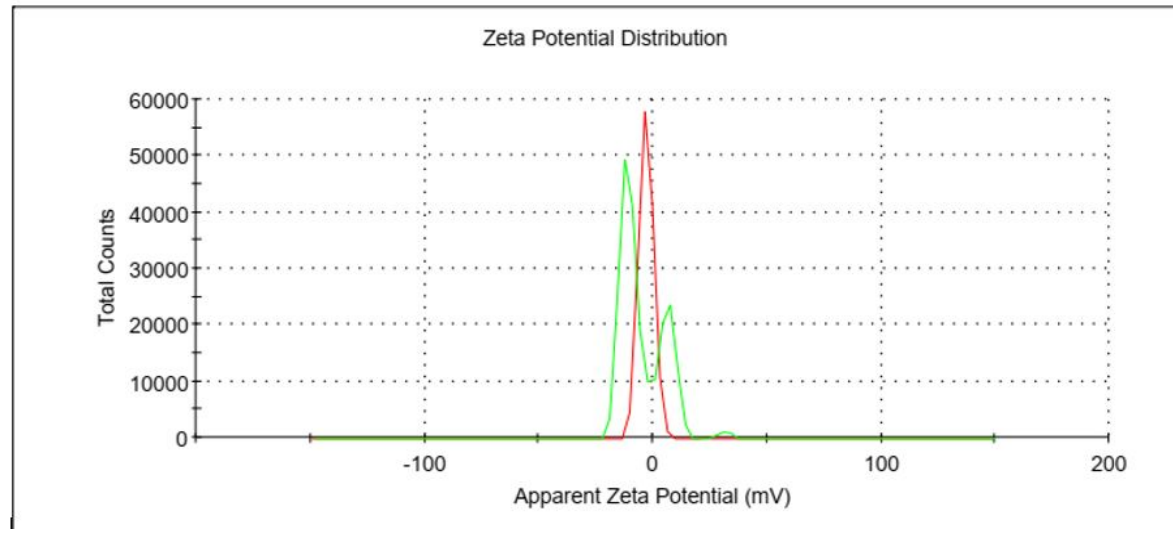

Figure 9. Zeta potential and net charge based on water solution made from (A) GLU 00 and (B) GLU 3.

Zeta potential is an essential physicochemical parameter that represents the native charges on a solvent system with the solute. Ionization may generate various amino acid residues are formed by partial ionization (Zhao et al., 2017). The hydrolysis led to the exposure of negatively charged ions, such as carboxyl groups. Therefore, the amino acids possessed many surfaces negative in Glu 00, however, the Glu 03 showed the increase in the charge towards the positive side (Figure 9). The same effect was described in the Molins (2001) where ionization generates free electrons from macromolecules like protein. The release of the free electron creates positive charges, and the same effect has been proved with zeta potential analysis.

\subsection{Secondary structure of protein and functional groups}

The FTIR spectra did not reflect any changes in Beta sheets and random coils and no noticeable changes were found in the region 1700 to $1600 \mathrm{~cm}^{-1}$. This indicates that the X-ray treatment does not affect intramolecular hydrogen bonds of beta-sheet proteins (Figure 10).

In Glu-00, absorption associated with $2258.8 \mathrm{~cm}^{-1}$ band leads to $\mathrm{N}=\mathrm{C}=\mathrm{O}$ stretching, which shows the presence of isocyanate functional group. Isocyanate group has numerous functions in mechanical and thermal properties. It tends to react with an amino group and the hydroxyl group of the protein molecule. However, since the sample was treated with irradiation, the $\mathrm{N}=\mathrm{C}=\mathrm{O}$ stretching band have disappeared. Mechanical and thermal properties might have been affected due to the absence of this band in the treated sample (Hemsri et al., 2009). 
In Glu-3, absorption associated with $1740 \mathrm{~cm}^{-1}$ bands has been corresponded to $\mathrm{C}=\mathrm{O}$. The carbonyl groups are chemically relevant. It is vital in the interpretation of infrared spectra. The carbonyl group present was consisted of aldehyde due to wavelength as well as the carbonyl group pointed toward a terminal group and had only one substituent group and one being a single hydrogen atom. Carbonyl group acts as a hydrogen acceptor and leads to hydrogen bonding. Hydrogen bonding is of considerable significance seeing that it leads to the formation of secondary and tertiary structures and thereby leads to the stabilization of protein molecules (Cole, 2000). X-ray irradiated protein can cause specific permanent changes such as decarboxylation, deamination, reduction of disulfide linkages, oxidation of sulfhydryl groups, modification of amino acid moieties, valence change of coordinated metal ions, peptide chain cleavage and aggregation (Kuan et al., 2013). The proteins are composed of many $\mathrm{NH}$ and $\mathrm{OH}$ functional groups that can donate hydrogen bonds, and $\mathrm{CO}$, and other groups accept them. Hydrogen bonds determine the secondary and tertiary structure of protein molecules (Kostal, 2016). Hydrogen bonds are not often the primary driving force determining the conformation and aggregation of globular proteins, but they do play a crucial role in stabilizing the structures once formed (Cole, 2000). The FTIR spectra showed that the $\mathrm{OH}$ group have been eliminated when the dose of irradiation has been increased. It might affect the secondary and tertiary structure of the protein, and thereby denaturation of protein might have occurred. Denaturation leads to unfolding, and exposure of hydrophilic and hydrophobic group took place, and water and oil holding capacities might have been increased (Margesin \& Schinner, 1999). The reaction between cysteine and cystine disulfide bonds exerts a strong influence on the functional properties of the protein (Gelita, 2018). The FTIR study revealed that as the irradiation dose increased, the thiol groups were eliminated. Disulfide bonds in intermolecular glutenin influence the viscoelastic property of wheat gluten protein (Hammann \& Schmid, 2014). So the disappearance of thiol group may affect the viscoelastic property of wheat gluten.

A

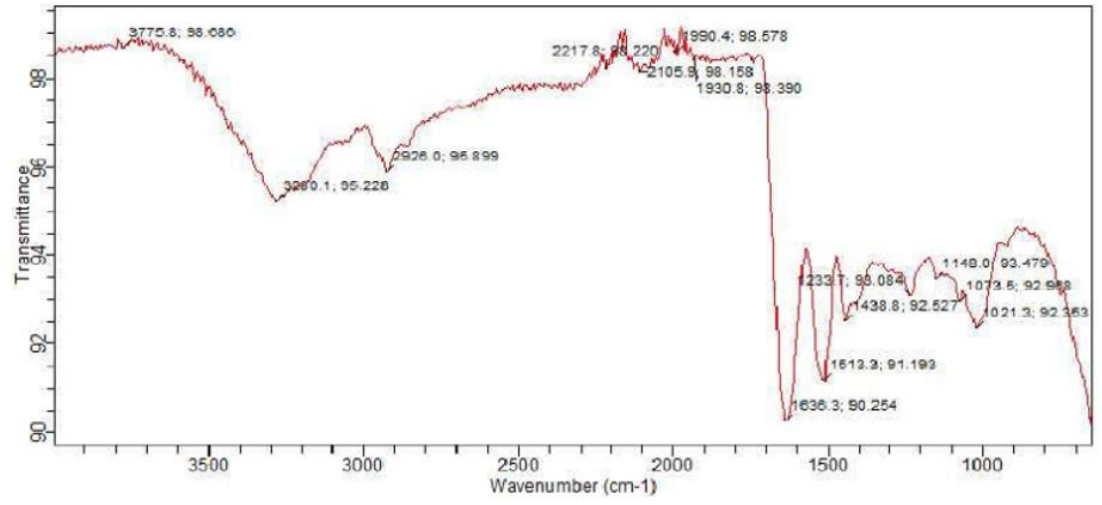

B

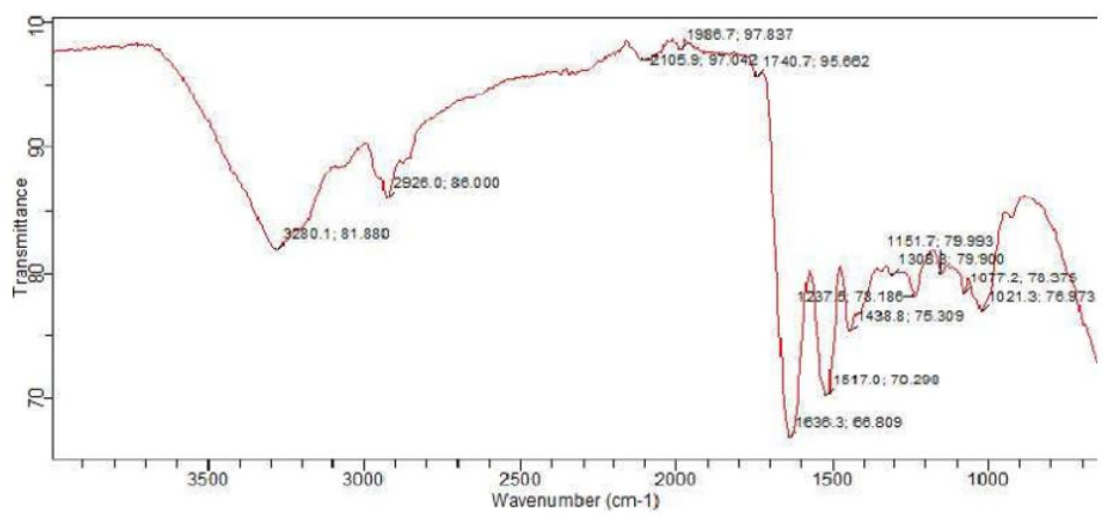

Figure 10. FTIR spectrum of (A) GLU 00 and (B) GLU 3. 


\section{Conclusion}

Gluten protein powder was treated with X-ray irradiation at $108 \mathrm{kV}$ for $1 \mathrm{sec}$ and 3-second and was also exposured to X-ray radiation. Functional and physiological properties of these treated gluten protein powder were studied and compared with untreated gluten protein powder. X-ray treatment resulted in improved water and oil holding capacities. These "tailor-made proteins" consisting of Good water holding capacity can be used in the preparation of bakery applications, soups, gravies, and due to their influence of oil holding capacity, they can also be used for cooking noodles and pasta. The X-ray treatment resulted in negative impacts on EAI and ESI. However, it was suspected that the excess of energy after increasing X-ray irradiation of prolonged dose may form too many hydrophobic regions within the GPP to be exposed to the exterior aqueous environment. This process, in turn, led to the aggregation of the proteins and finally the emulsion stability of GPP can be reduced. On the other hand, it has also influenced the FS as irradiation leads to protein unfolding and changes the protein nature. Owing to the influence of FS, it can be used to prepare ice-cream, cake, cream etc. Thus, the X-ray on gluten protein can alter the functional and physiological properties which can be used in food industry.

\section{Acknowledgements}

A special thanks to Diya Lab (Scientific \& Reference Laboratories) for obtaining FTIR and Particle Size Analysis results.

\section{References}

Ahmed, M. M., Abdalla, I. G., Salih, A. M., \& Hassan, A. B. (2018). Effect of gamma radiation on storability and functional properties of sorghum grains (Sorghum bicolor L.). Food Science \& Nutrition, 6(7), 1933-1939. http://dx.doi.org/10.1002/fsn3.752

Babiker, E. F. E., Fujisawa, N., Matsudomi, N., \& Kato, A. (1996). Improvement in the functional properties of gluten by protease digestion or acid hydrolysis followed by microbial transglutaminase treatment. Journal of Agricultural and Food Chemistry, 44(12), 3746-3750. http://dx.doi.org/10.1021/jf960302d

Ballesteros, L. F., Teixeira, J. A., \& Mussatto, S. I. (2014). Chemical, functional, and structural properties of spent coffee grounds and coffee silverskin. Food and Bioprocess Technology, 7(12), 3493-3503. http://dx.doi.org/10.1007/s11947-014-1349-

Barron, E. S. G., \& Finkelstein, P. (1952). Studies on the mechanism of action of ionizing radiations. X. Effect of X-rays on some physicochemical properties of proteins. Archives of Biochemistry and Biophysics, 41(1), 212-232. PMid:12997265. http://dx.doi.org/10.1016/0003-9861(52)90521-3

Cano-Medina, A., Jiménez-Islas, H., Dendooven, L., Herrera, R. P., González-Alatorre, G., \& Escamilla-Silva, E. M. (2011). Emulsifying and foaming capacity and emulsion and foam stability of sesame protein concentrates. Food Research International, 44(3), 684-692. http://dx.doi.org/10.1016/j.foodres.2010.12.015

Chang, S. K. C., \& Zhang, Y. (2017). Protein analysis (pp. 315-331). Cham: Springer. https://doi.org/10.1007/978-3-319-457765 .

Chau, C.-F., Cheung, P. C. K., \& Wong, Y.-S. (1997). Functional properties of protein concentrates from three Chinese indigenous legume seeds. Journal of Agricultural and Food Chemistry, 45(7), 2500-2503. http://dx.doi.org/10.1021/jf970047c

Cole, B. B. (2000). Managed futures: out of favor or outta here? Polar Investment Counsel

Farkas, J. (2006). Irradiation for better foods. Trends in Food Science \& Technology, 17(4), 148-152. http://dx.doi.org/10.1016/j.tifs.2005.12.003

Gelita. (2018). Functional properties. Gelita Service.

Hammann, F., \& Schmid, M. (2014). Determination and quantification of molecular interactions in protein films: A review. Materials, 7(12), 7975-7996. PMid:28788285. http://dx.doi.org/10.3390/ma7127975

Harder, M. N. C., Arthur, V., \& Arthur, P. B. (2015). Irradiation of foods: processing technology and effects on nutrients: effect of ionizing radiation on food components. In B. Caballero, P. M. Finglas \& F. Toldrá (Eds.), Encyclopedia of food and health (pp. 476-471). Amsterdam: Academic Press.

Hemsri, S., Simpson, C., Parnas, R., \& Asandei, A. D. (2009). Isocyanate, thiol, epoxide and hydroxy functionalized silane coated alumina/wheat gluten blends. Polymer Preprints, 50(1), 171-172.

Hmed, S. E. A., \& Osman, G. A. M. (2009). Effect of gamma irradiation on the physico-chemical characterstics of groundnut (Arachis Hypogaea). Australian Journal of Basic and Applied Sciences, 3(3), 2856-2860. 
Jongjareonrak, A., Srikok, K., Leksawasdi, N., \& Andreotti, C. (2015). Extraction and fundamental properties of protein from deoiled rice bran of rice bran oil production industry. Chiang Mai University Journal of Natural Sciences, 14(2), 163-174. http://dx.doi.org/10.12982/CMUJNS.2015.0079

Kaushik, R., Kumar, N., Sihag, M. K., \& Ray, A. (2015). Isolation, characterization of wheat gluten and its regeneration properties. Journal of Food Science and Technology, 52(9), 5930-5937. http://dx.doi.org/10.1007/s13197-014-1690-2

Kostal, J. (2016). Computational chemistry in predictive toxicology: status quo et quo vadis? Advances in Molecular Toxicology, 10, 139-186. http://dx.doi.org/10.1016/B978-0-12-804700-2.00004-0

Kovacs, M. I. P., Fu, B. X., Woods, S. M., \& Khan, K. (2004). Thermal stability of wheat gluten protein: its effect on dough properties and noodle texture. Journal of Cereal Science, 39(1), 9-19. http://dx.doi.org/10.1016/S0733-5210(03)00058-4

Kuan, Y.-H., Bhat, R., Patras, A., \& Karim, A. A. (2013). Radiation processing of food proteins: A review on the recent developments. Trends in Food Science \& Technology, 30(2), 105-120. http://dx.doi.org/10.1016/j.tifs.2012.12.002

Lee, N.-Y., Kang, C.-S., \& Kim, H.-S. (2017). Effects of Y-irradiation on the quality changes of fresh noodles prepared from wheat cultivated with N-fertilization treatments. Food Science and Biotechnology, 26(1), 135-142. PMid:30263520. http://dx.doi.org/10.1007/s10068-017-0018-1

Li, C., Huang, X., Peng, Q., Shan, Y., \& Xue, F. (2014). Physicochemical properties of peanut protein isolate-glucomannan conjugates prepared by ultrasonic treatment. Ultrasonics Sonochemistry, 21(5), 1722-1727. PMid:24703823. http://dx.doi.org/10.1016/j.ultsonch.2014.03.018

Margesin, R., \& Schinner, F. (1999). Cold-adapted organisms: Ecology, physiology, enzymology and molecular biology. Berlin: Springer. http://dx.doi.org/10.1007/978-3-662-06285-2.

Molins, R. A. (2001). Food irradiation: principles and applications. New York: Wiley.

Pollard, E. C. (1960). Effects of ionizing radiation on nucleoproteins. Cancer, 13(S6), 38-42. http://dx.doi.org/10.1002/10970142(196011/12)13:6+<38::AID-CNCR2820130709>3.0.CO;2-W

Roger, D. D., Jean-Justin, E. N., \& François-Xavier, E. (2007). Nutritive value, toxicological and hygienic quality of some cassava based products consumed in Cameroon. Pakistan Journal of Nutrition, 6(4), 404-408. http://dx.doi.org/10.3923/pjn.2007.404.408

Segat, A., Biasutti, M., lacumin, L., Comi, G., Baruzzi, F., Carboni, C., \& Innocente, N. (2014). Use of ozone in production chain of high moisture Mozzarella cheese. Lebensmittel-Wissenschaft + Technologie, 55(2), 513-520. http://dx.doi.org/10.1016/j.Iwt.2013.10.029

Sui, X., Bi, S., Qi, B., Wang, Z., Zhang, M., Li, Y., \& Jiang, L. (2017). Impact of ultrasonic treatment on an emulsion system stabilized with soybean protein isolate and lecithin: its emulsifying property and emulsion stability. Food Hydrocolloids, 63, 727734. http://dx.doi.org/10.1016/j.foodhyd.2016.10.024

Yalcin, E., Sakiyan, O., Sumnu, G., Celik, S., \& Koksel, H. (2008). Functional properties of microwave-treated wheat gluten. European Food Research and Technology, 227(5), 1411-1417. http://dx.doi.org/10.1007/s00217-008-0860-8

Yilmaz, E., \& Emir, D. D. (2016). Extraction and functional properties of proteins from pre-roasted and enzyme treated poppyseed (Papaver somniferum L.) press cakes. Journal of Oleo Science, 65(4), 319-329. PMid:26972462. http://dx.doi.org/10.5650/jos.ess15228

Yu, J., Ahmedna, M., \& Goktepe, I. (2007). Peanut protein concentrate: production and functional properties as affected by processing. Food Chemistry, 103(1), 121-129. http://dx.doi.org/10.1016/j.foodchem.2006.08.012

Zhao, Y., Sun, N., Li, Y., Cheng, S., Jiang, C., \& Lin, S. (2017). Effects of electron beam irradiation (EBI) on structure characteristics and thermal properties of walnut protein flour. Food Research International, 100(Pt 1), 850. PMid:28873758. http://dx.doi.org/10.1016/j.foodres.2017.08.004

Funding: None. 